\title{
Unexpected impacts of climate change on alpine vegetation
}

\author{
Nicoletta Cannone ${ }^{1 *}$, Sergio Sgorbati ${ }^{2}$, and Mauro Guglielmin ${ }^{3}$
}

The vegetation in a high alpine site of the European Alps experienced changes in area between 1953 and 2003 as a result of climate change. Shrubs showed rapid expansion rates of $5.6 \%$ per decade at altitudes between $2400 \mathrm{~m}$ and $2500 \mathrm{~m}$. Above $2500 \mathrm{~m}$, vegetation coverage exhibited unexpected patterns of regression associated with increased precipitation and permafrost degradation. As these changes follow a sharp increase in both summer and annual temperatures after 1980, we suggest that vegetation of the alpine (2400-2800 $\mathrm{m}$ ) and nival (above $2800 \mathrm{~m}$ ) belts respond in a fast and flexible way, contradicting previous hypotheses that alpine and nival species appear to have a natural inertia and are able to tolerate an increase of $1-2^{\circ} \mathrm{C}$ in mean air temperature.

Front Ecol Environ 2007; 5(7): 360-364

$\mathrm{T}$ he Intergovernmental Panel on Climate Change (IPCC) determined that, during the 20th century, global air temperature warmed by an average of $0.6 \pm 0.2^{\circ} \mathrm{C}$ (95\% CI; IPCC 2001). This pattern was not uniform over the planet and, in the European Alps, the increase in air temperature was more than twice as great as the increase in global mean air temperature (Böhm et al. 2001). Neither were changes in the precipitation regime spatially or temporally uniform; in the central Alps, precipitation increased by up to $10 \%$ between 1900 and 2000 (IPCC 2001).

There is ample evidence to indicate that recent climatic changes have affected a broad range of organisms, with consequences that are already discernible in phenology and distribution of species, community composition, and ecosystem structure and dynamics (Walther et al. 2002). Quantitative estimates of such biological impacts have led to the recognition of a climate change "fingerprint", with greater amplitude expected at high latitudes and altitudes (Root et al. 2003).

In alpine environments, abiotic factors, especially climate, dominate biotic interactions. Although the impact of short-term climatic fluctuations on alpine vegetation is expected to be negligible because of the slow growth rates and extended life cycles of species (Pauli et al. 1999), high altitude vegetation is anticipated to be more sensitive to long-term climate change (Gottfried et al. 1998; Theurillat and Guisan 2001). Evidence of the sensitivity of alpine habitats is provided by shifts in the altitudinal-range margins of plant species and bioclimatic zones in the past 50 years, with upward displacement of 120-340 m for tree and woody shrub species (Kullman 2002), upward migration of alpine and nival plant species at a rate of $8-10 \mathrm{~m}$ per decade (Grabherr et al. 1994;

${ }^{1}$ Department of Biology and Evolution, Ferrara University, Ferrara, Italy *(nicoletta.cannone@unife.it); ${ }^{2}$ Dipartimento di Scienze dell'Ambiente e del Territorio, University Milano-Bicocca, Milano, Italy; ${ }^{3}$ Dipartimento di Biologia Strutturale e Funzionale, Insubria University, Varese, Italy
Walther et al. 2005), and changes in community composition (Keller et al. 2000).

In the Alps, landscape changes are complicated by the millenia-old influence of human activities, making it difficult to distinguish between the effects of climate warming and land-use modification. However, the alpine (2400-2800 m above sea level [asl]) and nival (> $2800 \mathrm{~m}$ asl) belts - where anthropogenic land-use effects are negligible - provide natural models of change that are exclusively influenced by climate warming (Keller et al. 2005). Indeed, the alpine-nival ecotone may serve as an early indicator of climate-change impacts, because even smallscale migration is likely to cause fundamental changes in species composition (Gottfried et al. 1998).

The effects of climate change are likely to be detectable at lower tiers of ecological organization (eg species composition, functional pathways) before affecting higherlevel ecological systems (Neilson 1993). In this paper, we focus on high altitude habitats and investigate the level of ecological hierarchy at which climate change can be seen, by analyzing changes in vegetation distribution, community dynamics, and vegetation series (ie shrublands, grasslands, wetlands) in the Italian Alps for the period 1950-2003.

The study area was located around Stelvio Pass (46 $31^{\prime}$ $\mathrm{N}, 10^{\circ} 25^{\prime}$ E; elevation 2230-3094 m asl; investigated area $5.6 \mathrm{~km}^{2}$ ), a high alpine site in Stelvio National Park in the Italian Central Alps. At the elevation of our site, the only anthropogenic land use is extensive summer pasturing. Historical archives indicate that pasturing has remained nearly constant since 1950, allowing us to exclude land-use change as a driver of vegetation change since that time.

\section{Methods}

Using GIS, we compared a phytosociological map from 1953 (Giacomini and Pignatti 1955) with a new map that we constructed in 2003. The 1953 map and the 2003 map 
drawn in the field were both scanned at high resolution and geocoded using the same software, ArcView GIS 3.2. Vegetation changes were calculated using three different measures: coverage, dynamics, and ecological series. Changes in coverage were classified into three groups: bare ground, discontinuous vegetation, and continuous vegetation. Vegetation dynamics were linked to successional changes and/or invasion by associations of plants from different altitudinal belts. The ecological series of habitat types were calculated using the seven main vegetation series (shrublands, grasslands, wetlands, snowbeds, pioneer, other, bare ground). The vegetation changes (in coverage, dynamics, and ecological series) were measured with reference to area (ie increase in area, no change in area, decrease in area) and to elevation (ie upward extension, no altitudinal change, downward extension).

Air temperature and precipitation records for the study period were provided by the two closest available stations, Sils (located $50 \mathrm{~km}$ from the study area, at 46 $26^{\prime}$ N, 946' E; elevation $1798 \mathrm{~m}$ asl; Begert et al. 2005) and Silandro (located $25 \mathrm{~km}$ from the study area, at $46^{\circ} 37^{\prime} \mathrm{N}$, $10^{\circ} 46^{\prime}$ E; elevation $718 \mathrm{~m}$ asl). For snow cover, data from 1978 onward were provided from the closest available station, Cancano (located $9 \mathrm{~km}$ from the study area, at $46^{\circ} 31^{\prime} \mathrm{N}, 10^{\circ} 18^{\prime} \mathrm{E}$; elevation $1948 \mathrm{~m}$ asl).

\section{Results}

The climatic conditions of the Alps changed between 1950 and 2003 (Figure 1). The mean annual air temperature increased, with a more pronounced rise since 1980 , at Silandro $\left(+1.0^{\circ} \mathrm{C}\right)$ and Sils $\left(+1.2^{\circ} \mathrm{C}\right)$. The seasonal patterns of air temperature indicate an overall increase for summers (June-August) at both stations, with a sharp increase after $1980\left(+1.1^{\circ} \mathrm{C} 1990-1999\right.$ at Silandro, $+0.42^{\circ} \mathrm{C} 1980-89$, and $+1.02^{\circ} \mathrm{C} 1990-99$ at Sils, relative to 1961-1990 averages), conforming to a trend described for the whole of Switzerland (Begert et al. 2005).

The precipitation pattern is less clear, with large fluctuations within the considered time span. Total precipitation increased, especially after $1980(+10 \%$ at Silandro and $+7 \%$ at Sils with respect to the reference values of 1961-1990), in agreement with Walther et al. (2002), who identified a $10 \%$ increase in precipitation. The seasonal patterns also indicated a general increase in precip- itation, except in the winter season, which showed a remarkable decrease, with the lowest values occurring in the past decade. Since 1978, the snow depth recorded at Cancano decreased and the length of the snow season shortened as well (Figure 2), due to summer warming and a reduction in snow fall.

Climate warming induced permafrost degradation, as indicated by the thermal profile within a deep borehole located $1 \mathrm{~km}$ east of Mt Scorluzzo. We observed an increase in permafrost temperature of $1.2^{\circ} \mathrm{C}$ since 1950 (Guglielmin 2004). The last glacier body (located in the study area on the northern slope of Mt Scorluzzo) completely disappeared between 1930 and 1958 .

The vegetation changes between 1950 and 2003 show a general pattern of increase in coverage, with a shift toward late successional and climax stages, the appearance of communities from the lower altitudinal belts, and upward displacement of shrublands to $2500 \mathrm{~m}$ asl. Above this threshold, there are contrasting patterns, with the same expected impacts as recorded below, but with some unexpected regressions and decreases in coverage. The changes in coverage type indicated that, over the whole area, increases exceeded decreases (22.1\% versus $11.6 \%$ ); overall, spatial patterns were heterogeneous (Figure $3 \mathrm{a}$ ). The greatest change occurred between 2230 and $2500 \mathrm{~m}$ and was associated with an increase in coverage, mainly from discontinuous to continuous vegetation, although there are patchy areas where coverage decreased. Above $2500 \mathrm{~m}$, the increase in coverage was more modest, with 


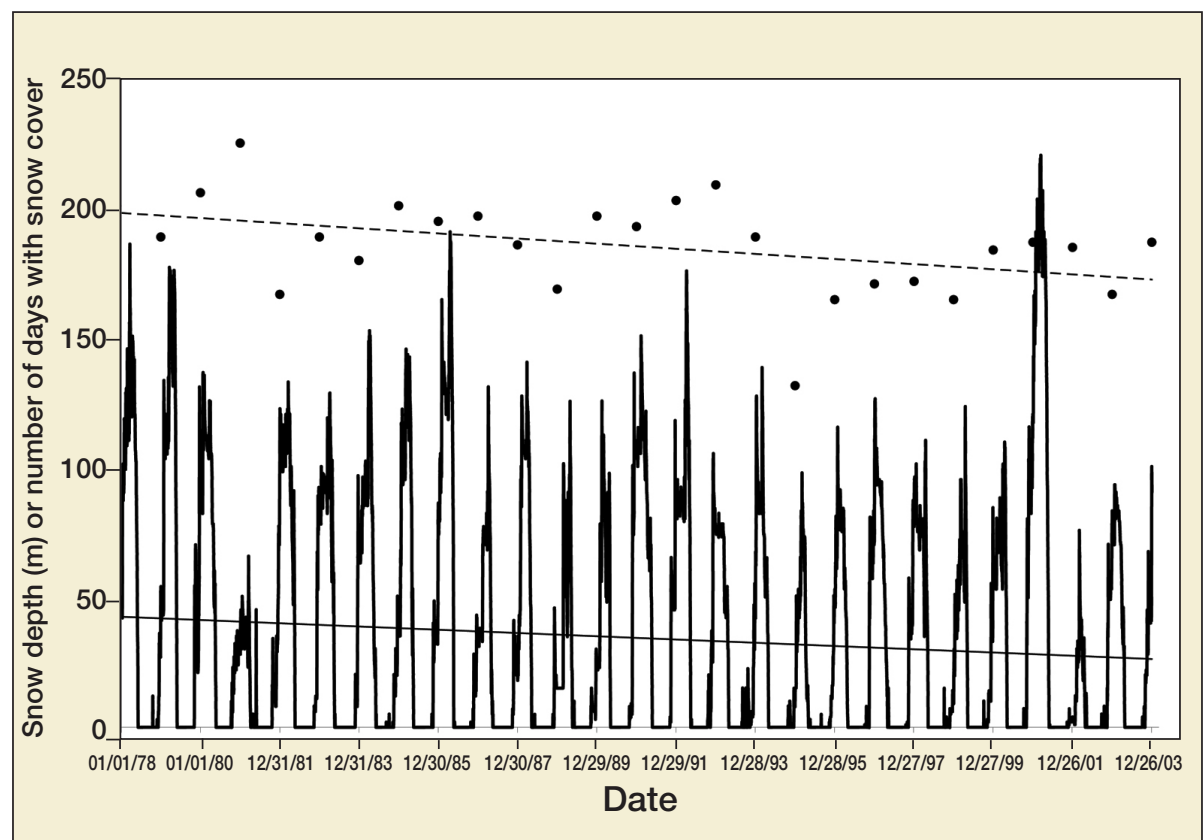

Figure 2. Snow patterns recorded at Cancano between 1978 and 2003, with the daily snow depth measured at the ground (solid thick line) and its linear regression (solid light line), the total number of days with snow cover per year (black dots) and its linear regression (dashed line). Despite the high annual variability of the snow depth, the general pattern shown by the linear regression indicates a decrease in both snow depth and snow permanence.

the exception of 2650-2700 $\mathrm{m}$ and above $2800 \mathrm{~m}$, where there was a decrease in coverage.

The vegetation dynamics of the area as a whole indicate similar patterns of change, with expansion exceeding regression $(34.8 \%$ versus $20.2 \%)$. The spatial distribution of the changes (Figure $3 \mathrm{~b}$ ) indicates that expansion largely prevails between 2230 and $2500 \mathrm{~m}$ asl, whereas, above $2500 \mathrm{~m}$, expansion was slightly greater than or equal to regression. These patterns suggest that the changes in distribution are often asymmetrical, with species invasions from lower elevations moving faster than the upslope retreat of resident species (Walther et al. 2002).

The changes in the ecological series indicate a cascade effect (Table 1), with the arrival of the alpine shrubland and upward displacement of the alpine grassland (especially between 2230 and $2500 \mathrm{~m}$ ). The shrub invasion is due to the expansion and upward displacement of the pre-existing association, dominated by the dwarf shrub Loiseleuria procumbens, and by the arrival of vegetation from the subalpine belt, an association characterized by Rhododendron ferrugineum (Figure 4 a,b). The expansion and upward migration of the alpine shrubland matches similar observations of shrub invasion of grasslands by Vaccinium uliginosum in the alpine belt of the European Alps (Bahn and Körner 2003).

The average increase in coverage by shrubs and dwarf shrubs was $+1.9 \%$ per decade over the whole area, with the highest rates of expansion occurring below 2500 $\mathrm{m} \quad(+6.6 \%$ per decade at $2230-2400 \mathrm{~m} ;+5.6 \%$ per decade at $2400-2500 \mathrm{~m}$ ). This rapid migration of the shrub-line was even greater than that observed in the Arctic, where the cover of tall shrubs in the tundra has increased by $1.2 \%$ per decade, mainly in response to summer warming (ranging between $0.15-0.17^{\circ} \mathrm{C}$ to $0.3-0.4^{\circ} \mathrm{C}$ per decade; Chapin et al. 2005). The sharp increase in summer temperatures (up to $+1.1^{\circ} \mathrm{C}$ per decade) that occurred at our site after 1980 may explain this rapid increase in shrub coverage, despite the summer cooling recorded from 1960 to 1979.

\section{Discussion}

The expansion of shrubs within the alpine belt may indicate a modification of the competitive relations among shrub-plant functional types (ie $R$ ferrugineum), with dwarf shrubs (ie L procumbens) and chamaephytes (ie $V$ uliginosum) displacing hemicryptophytes (ie Carex curvula), as hypothesized by Theurillat and Guisan (2001). The decrease in the length of the snow cover season may be responsible for the increase in $L$ procumbens and $V$ uliginosum, which are typical of windswept areas,

\begin{tabular}{|c|c|c|c|c|c|c|c|}
\hline Habitat & $\begin{array}{c}2230-2400 \\
m \text { asl }\end{array}$ & $\begin{array}{c}2400-2500 \\
m \text { asl }\end{array}$ & $\begin{array}{c}2500-2600 \\
\mathrm{~m} \text { asl }\end{array}$ & $\begin{array}{c}2600-2700 \\
m \text { asl }\end{array}$ & $\begin{array}{c}2700-2800 \\
m \text { asl }\end{array}$ & $\begin{array}{c}2800-2900 \\
\mathrm{~m} \text { asl }\end{array}$ & $\begin{array}{l}\text { Average } \\
\text { whole area }\end{array}$ \\
\hline Shrubs & +33.3 & +28.1 & -3.5 & -1.3 & $\mathrm{n} / \mathrm{a}$ & $\mathrm{n} / \mathrm{a}$ & +9.4 \\
\hline Grasslands & -31.3 & -30.7 & +14.6 & -2.3 & +9.0 & -8.0 & -8.1 \\
\hline Wetlands & -6.6 & -0.5 & -2.2 & -2.3 & $\mathrm{n} / \mathrm{a}$ & $\mathrm{n} / \mathrm{a}$ & -1.9 \\
\hline Snowbed & $\mathrm{n} / \mathrm{a}$ & -1.6 & $-\mid 4.1$ & +3.9 & +2.4 & $\mathrm{n} / \mathrm{a}$ & -1.6 \\
\hline Pioneer & +2.3 & +2.9 & +7.1 & -5.0 & +7.7 & -31.0 & -2.7 \\
\hline Other & +0.1 & $\mathrm{n} / \mathrm{a}$ & +0.6 & $\mathrm{n} / \mathrm{a}$ & $\mathrm{n} / \mathrm{a}$ & $\mathrm{n} / \mathrm{a}$ & +0.1 \\
\hline Bare ground & +2.2 & +1.8 & -2.5 & +7.0 & -19.1 & +39 & +4.7 \\
\hline
\end{tabular}




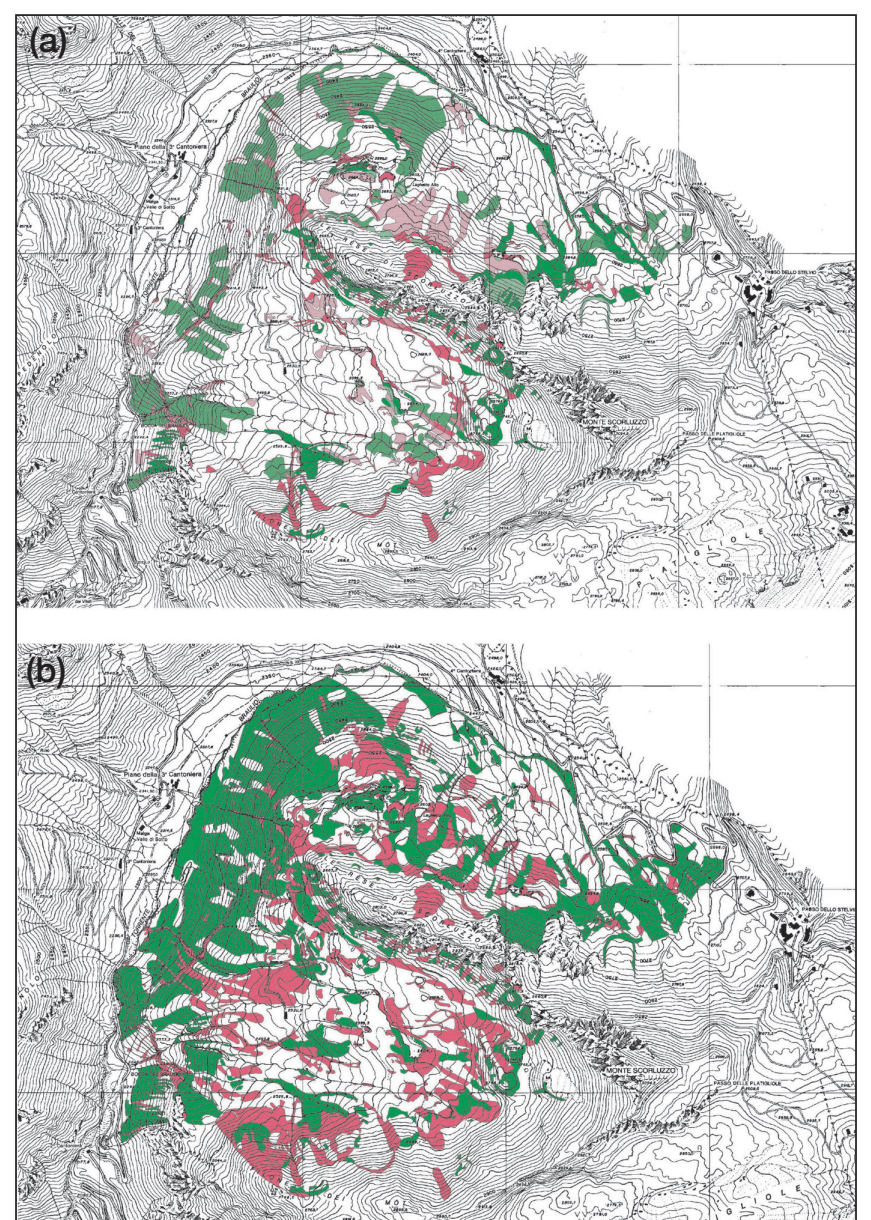

Figure 3. (a) Changes in coverage type between 1953 and 2003 in the Stelvio Pass area (central Italian Alps). Solid magenta = coverage decrease from continuous vegetation to bare ground; magenta stripes $=$ coverage decrease from continuous to discontinuous vegetation; pale magenta $=$ coverage decrease from discontinuous vegetation to bare ground; solid green = coverage increase from bare ground to continuous vegetation; green dots = coverage increase from bare ground to discontinuous vegetation; green stripes $=$ coverage increase from discontinuous to continuous vegetation. (b) Changes in vegetation dynamics between 1953 and 2003 in the Stelvio Pass area (central Italian Alps). Magenta $=$ shift toward early successional and/or pioneer stages of succession (ie from the climax alpine grassland Caricetum curvulae to the pioneer vegetation Oxyrietum digynae) and/or ingression of associations from higher altitudinal belts (ie from the alpine grassland to the alpine shrubland); green = shift toward late successional and/or climax stages (ie from pioneer vegetation to climax alpine grassland) and/or ingression of associations from lower altitudinal belts (ie from alpine shrubland to alpine grassland).

instead of $R$ ferrugineum, which requires a longer and thicker snow cover.

There was also an upward migration of the alpine grassland (mainly 2500-2600 m), replacing the snowbeds, which in turn shifted upward (2600-2800 m; Figure 3b; Table 1). Above $2500 \mathrm{~m}$, the alpine grassland was invaded by the alpine shrub $\mathrm{V}$ uliginosum, which migrated

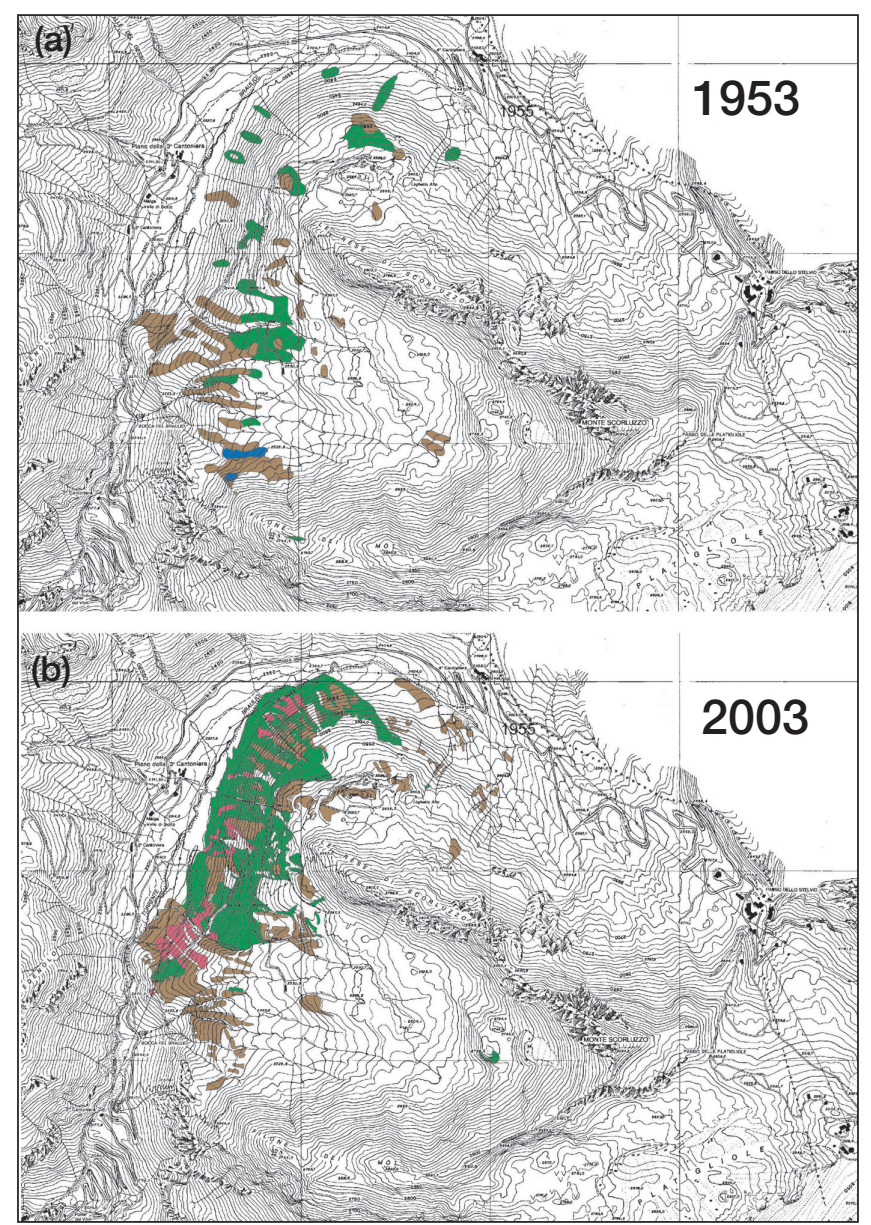

Figure 4. (a) Shrub distribution in 1953 in the Stelvio Pass area (central Italian Alps). Brown = dwarf shrub association (Loiseleurietum-Cetrarietum); green = mosaic between the dwarf shrub association (Loiseleurietum-Cetrarietum) and the alpine grassland; blue = mosaic between the dwarf shrub association (Loiseleurietum-Cetrarietum) and the snowbeds; (b) Shrub distribution in 2003 in the Stelvio Pass area (central Italian Alps). Brown = dwarf shrub association (Loiseleurietum -Cetrarietum); green = mosaic between the dwarf shrub association (Loiseleurietum-Cetrarietum) and the alpine grassland; magenta = alpine shrub association (RhodoretoVaccinietum).

upward to elevations of more than $2650 \mathrm{~m}$.

Overall, the upward movement of the grassland vegetation confirms the ability of late successional species such as $\mathrm{C}$ curvula to migrate, and corroborates experimental studies suggesting that a moderate warming of $1-2^{\circ} \mathrm{C}$ may favor upward colonization by alpine climax grassland, dominated by $\mathrm{C}$ curvula. The contraction of the snowbeds and their shift to higher altitudes is consistent with the shortening of the snow cover season and suggests that species that require long periods of snow cover might find refugia at higher altitudes (Keller et al. 2005).

Wetland vegetation also experienced a regression, especially at lower altitudes (Table 1). Pioneer vegetation, on the other hand, showed increased coverage below $2600 \mathrm{~m}$, although there were contrasting and unexpected patterns 
above $2600 \mathrm{~m}$; it decreased between 2600 and $2700 \mathrm{~m}$ and above $2800 \mathrm{~m}$, but increased between 2700 and $2800 \mathrm{~m}$. In addition, the pioneer vegetation showed a dynamic regression due to invasion by Androsacetum alpinae, the earliest colonizer during succession, mainly above $2500 \mathrm{~m}$. Bare ground coverage showed opposite trends with respect to the pioneer vegetation above $2500 \mathrm{~m}$. These results are unexpected in light of simple models which predicted upward displacement of vegetation in response to climate change and of earlier evidence, at the species level, which confirmed an upward migration of alpine and nival species (Grabherr et al. 1994; Walther et al. 2005), shifting at a rate of 8-10 m per decade on the mountain summits of the Austrian Alps (Grabherr et al. 1994).

Hydrological context is particularly important for interpreting the altered spatial distribution of pioneer vegetation. At the lower altitudes, increases in such species were mainly associated with streams and alluvial and debris flow fans, while at the higher altitudes, regressions were mainly seen on steep slopes. Increased summer precipitation and early snow melt may result in greater hydrological disturbance (eg flooding, debris flow), leading to both rejuvenation of vegetation and increased amounts of bare ground. At the higher altitudes, degradation of the permafrost, which has been occurring since 1950 - as documented by the permafrost temperature recorded in a deep borehole at the boundary of the study area (Guglielmin 2004) - may also trigger disturbances, in the form of debris flow and landslides (Williams 1995).

Our results indicate that both the increase in mean annual air temperature of $1.0-1.2^{\circ} \mathrm{C}$ between 1950 and 2003, the summer warming of $0.4-1^{\circ} \mathrm{C}$ per decade after 1980 , and the shortening of the snow season may activate feedback mechanisms (Chapin et al. 2005), able to cause vegetation changes at the community level. According to Neilson (1993), only high levels of climatic change lead to detectable signals in the upper levels of ecological hierarchies. Moreover, Pauli et al. (1999) suggest that only long-term climatic changes are able to produce significant changes in vegetation patterns in the alpine and nival belts.

In contrast with most studies on alpine and nival species (Theurillat and Guisan 2001), our data suggest that even $1-2^{\circ} \mathrm{C}$ warming of air temperature may produce important changes in vegetation community dynamics. In addition to expected effects (eg species and community displacement), unexpected effects may also have unpredictable consequences for biodiversity. For example, increased surface instability and disturbance - which probably caused the unexpected regressions above $2600 \mathrm{~m}$ in this study may create a migration barrier that restricts the colonization of higher altitudes to disturbance-adapted species. As the increase in summer and annual temperatures is almost entirely confined to the past two decades, we suggest that alpine and nival vegetation may respond faster and more flexibly to climatic change than was previously believed to be possible (Pauli et al. 1999; Walther et al. 2005).

\section{Acknowledgements}

We wish to thank P Convey and C Körner for reviewing this paper prior to submission, Stelvio National Park for logistical support, the Swiss Meteorological Service, the Metereological Service of Bolzano, Azienda Elettrica Milanese (AEM) for climatic data, M De Amicis for GIS support, and A Pisterna and L Abbate for field assistance.

\section{References}

Bahn M and Körner C. 2003. Recent increases in summit flora caused by warming in the Alps. Ecol Stud 167: 437-41.

Begert M, Schlegel T, and Kirchhofer W. 2005. Homogeneous temperature and precipitation series of Switzerland from 1864 to 2000. Int J Climatol 25: 65-80.

Böhm R, Auer I, Brunetti M, et al. 2001. Regional temperature variability in the European Alps: 1760-1998 from homogenized instrumental time series. Int J Climatol 21: 1779-1801.

Chapin FS, Sturm M, Serreze MC, et al. 2005. Role of land-surface changes in Arctic summer warming. Science 310: 657-60.

Giacomini V and Pignatti S. 1955. Flora e vegetazione dell'Alta Valle del Braulio con speciale riferimento ai pascoli d'altitudine. Mem Soc Ital Sc Nat 11: 47-238.

Gottfried M, Pauli H and Grabherr G. 1998. Prediction of vegetation patterns at the limits of plant life: a new view of the alpine-nival ecotone. Arctic Alpine Res 30: 207-21.

Grabherr G, Gottfried M, and Pauli H. 1994. Climate effects on mountain plants. Nature 369: 448

Guglielmin M. 2004. Observations on permafrost ground thermal regimes from Antarctica and the Italian Alps, and their relevance to global climate change. Global Planet Change 40: 159-67.

IPCC (Intergovernmental Panel on Climate Change). 1996. Second assessment report of the Intergovernmental Panel on Climate Change. Cambridge, UK: Cambridge University Press.

IPCC (Intergovernmental Panel on Climate Change). 2001. Third assessment report of the Intergovernmental Panel on Climate Change. Cambridge, UK: Cambridge University Press.

Keller F, Kienast F, and Beniston M. 2000. Evidence of response of vegetation to environmental change on high-elevation sites in the Swiss Alps. Reg Environ Change 1: 70-77.

Keller F, Goyette S, and Beniston M. 2005. Sensitivity analysis of snow cover to climate change scenarios and their impact on plant habitats in alpine terrain. Clim Change 72: 299-319.

Kullman L. 2002. Rapid recent range-margin rise of tree and shrub species in the Swedish Scandes. J Ecol 90: 68-77.

Neilson RP. 1993. Transient ecotone response to climatic change: some conceptual and modelling approaches. Ecol Appl 3 385-95.

Pauli H, Gottfried M, and Grabherr G. 1999. Vascular plant distribution patterns at the low temperature limits of plant life - the alpine-nival ecotone of Mount Schrankogel (Tyrol, Austria). Phytocoenologia 29: 297-325.

Root TL, Price JT, Hall KR, et al. 2003. Fingerprints of global warming on wild animals and plants. Nature 421: 57-60.

Theurillat JP and Guisan A. 2001. Potential impact of climate change on vegetation in the European Alps: a review. Clim Change 50: 77-109.

Walther G, Post E, Convey P, et al. 2002. Ecological responses to recent climate change. Nature 416: 389-95.

Walther G-R, Beißner S, and Burga CA. 2005. Trends in the upward shift of alpine plants. J of Veg Sci 16: 541-48.

Williams PJ. 1995. Permafrost and climate change - geotechnical implications. Philos T Roy Soc A 352: 347-58. 